\title{
PERANGKAT LUNAK
}

\section{MINI TINJAUAN MEDIA PEMBELAJARAN BERBASIS PERANGKAT LUNAK KOMPUTER}

\author{
Nurul Huda Zuhdi \\ (0305203110) \\ Program Studi Pendidikan Matematika \\ FakultasIlmuTarbiahdan Keguruan,UIN SumateraUtara \\ Email : nurulhudazuhdii@gmail.com
}

\begin{abstract}
ABSTRAK
Penelitian ini bertujuan untuk meningkatkan media pendidikan berbasis komputer. Secara khusus perlu ditentukan tingkat profesionalitas mahasiswa dalam mengimplementasikan sistem operasi pada media pembelajaran. Sistem operasi adalah antarmuka antara pengguna PC dan perangkat keras komputer. Penggunaan teknologi tidak bisa dihindari, seperti halnya dalam bidang pembelajaran. Menggunakan berbagai alternatif aplikasi software yang dapat digunakan sebagai media pendidikan untuk mengoptimalkan perangkat komputer yang ada termasuk bentuk upaya untuk meningkatkan konsentrasi dan mencapai hasil belajar. Postingan ini bertujuan buat mengamati hasil perancangan, pengembangan serta implementasi media pendidikan berbasis fitur lunak. Ada juga media pembelajaran berbasis software, yang sering digunakan dalam bentuk video pendidikan, e-learning, e-book, dan simulator (fungsi software simulasi). Hasil dari riset ini merupakan rancangan perangkat lunak untuk membangun suatu sistem data yang bisa terintegrasi antara administrasi, akademik serta pimpinan sebagai pihak yang memonitor kemajuan lembaga, dan memacu proses pelayanan administrasi serta pelayanan akademik.
\end{abstract}

Kata Kunci: media pembelajaran, perangkat lunak, komputer. 


\begin{abstract}
This study aims to improve computer-based educational media. In particular, it is necessary to determine the level of professionalism of students in implementing the operating system on learning media. The operating system is the interface between the PC user and the computer hardware. The use of technology is unavoidable, as is the case in the field of learning. Using various alternative aplikasi applications that can be used as educational media to optimize existing computer devices, including efforts to increase concentration and achieve learning outcomes. There are also software- based learning media, which are often used in the form of educational videos, e- learning, ebooks, and simulators (simulation aplikasi functions). The result of this research is a software design to build a data system that can be integrated between administration, academic and leadership as the party that monitors the progress of the institution, and spurs the process of administrative services and academic services.
\end{abstract}

Keywords: learning media, software, computer. 


\section{PENDAHULUAN}

Pesatnya pertumbuhan ilmu pengetahuan serta teknologi bawa akibat yang lumayan besar terhadap media pendidikan. Pelaksanaan media pendidikan dalam bidang pembelajaran sudah melahirkan banyak terobosan baru dalam tingkatkan efisiensi serta efektifitas proses pendidikan. Peluang tersebut hendak penulis manfaatkan buat meningkatkan media pendidikan. Pesatnya pertumbuhan pembelajaran di Indonesia pula sudah didukung oleh pemerintah, dalam perihal ini Departemen Pembelajaran sudah berkomitmen buat memperbaiki sistem pembelajaran di Indonesia. Kami berharap bisa tingkatkan sumber energi manusia lewat lulusan terbaik, tidak cuma secara kuantitas namun pula mutu, sehingga lulusan pembelajaran Indonesia bisa bersaing dengan lulusan dari luar negeri. Bagi Arsyad( 2011: 4), terdapat 2 aspek yang sangat berarti dalam dunia pendidikan, ialah tata cara pendidikan serta media pendidikan sebagai perlengkapan peraga.
Guru harus dapat memanfaatkan perkembangan teknologi sebagai media pendidikan dan memberikan kesempatan kepada siswa untuk berinteraksi dan berbicara secara aktif dengan teman sekelas dan guru. Pengembangan media pendidikan merupakan bentuk persiapan media. Oleh karena itu, pengembangan media pendidikan dapat memperbaiki media yang digunakan sebelumnya. Disisi lain, perkembangan teknologi data dan komunikasi sangat pesat, termasuk pembelajaran. Berbagai model pendidikan berbasis teknologi telah banyak digunakan dalam proses pengajaran.

Mudahnya menghasilkan fitur pc di dekat kita disaat ini jadi kesempatan yang baik buat dimanfaatkan dalam konsumsi media belajar.

Beberapa dorongan fasilitas perangkat komputer baik dari pemerintah ataupun antar sekolah, dan padahp sendiri hampir semua peserta didik menjadikan motivasi terbanyak buat memaksimalkan komputer serta hp yang terdapat dengan dorongan perangkat lunak( aplikasi) jadi media pendidikan yang efisien, kreatif serta berinovasi yang bisa tingkatkan atensi serta 
pencapaian belajar peserta didik demi terwujudnya kenaikan mutu kualitas Pembelajaran secara keseluruhan.

Beberapa penelitian yang dilakukan pada tingkatan perguruan tinggi pada bidang Pembelajaran untuk merancang dan mengevaluasi pelaksanaan bermacam media pendidikan pada setiap sekolah serta pembahasan materi tertentu demi terciptanya kenaikan atensi serta pencapaian belajar peserta didik.

Revolusi Modern 4.0 telah membawa kemajuan kreasi massal yang dapat disesuaikan (Kagermann et al., 2013). Mesin perlu bekerja secara mandiri atau sebagai tim dengan orang-orang (Sung, 2018). Salah satunya mengkoordinir pelatihan dengan memanfaatkan media portabel yang dapat dimanfaatkan pada (PC). Perspektif yang menjunjung tinggi pencapaian Penentuan media pembelajaran yang tepat direncanakan agar pelatihan sesuai dengan kualitas siswa atau materi pembelajaran.Oleh karena itu, seorang instruktur harus memiliki pilihan untuk memilih media pembelajaran yang tepat untuk membantu interaksi instruktif yang dididik.Siswa tidak melanjutkannya di luar pembicaraan dengan alasan bahwa tidak semua siswa memiliki workstation atau PC di rumah

Smaldino, dkk.(AL).(2002) mengungkapkan bahwa media adalah kantor surat menyurat. Sanjaya (2008) menarangkan kalau media pendidikan mempunyai khasiat dan khasiat buat:( 1) Menangkap barang ataupun kejadian tertentu; ( 2) Memanipulasi keadaan, peluang, ataupun postingan tertentu; $\operatorname{serta}(3)$ Tingkatkan tenaga serta inspirasi siswa buat belajar. Redondo, et angkatan laut( Angkatan laut(AL)).( 2013) melaporkan kalau siswa terpenuhi serta terbujuk oleh metode baru yang digunakan, serta inovasi bisa menolong meningkatkan prestasi belajar siswa lebih lanjut.

Thitiporn (2015) melaporkan kalau pelaksanaan perlengkapan pendidikan membuat siswa menguasai materi dalam waktu yang lebih pendek. Maka dari itu artikel ini bertujuan mengamati sebagian alternatif media pendidikan berbasis perangkat lunak (software) dari riset pustaka yang sudah dilakukan. Perihal ini diharapkan sanggup jadi rujukan media pendidikan yang hendak diterapkan. 


\section{STUDI LITERATUR}

Bertujuan untuk mendukung serta meningkatkan uraian terhadap suatu objek penelitian. Pada Riset ini peneliti hendak melaksanakan pendalaman yang lebih luas serta mendalam terhadap permasalahan yang dicoba oleh peneliti dengan mengumpulkan beberapa buku buku, ataupun jurnal jurnal yang berhubungan dengan permasalahan serta tujuan penelitian. Metode ini dicoba dengan tujuan buat mengungkapkan bermacam teori- teori yang relevan dengan kasus yang lagi dialami/ diteliti selaku bahan referensi dalam pembahasan hasil penelitian.

\section{METODE PENELITIAN}

Wujud penelitian yang digunakan dalam penelitian ini ialah tata cara penelitian kualitatif. Penelitian kualitatif ialah penelitian yang bersifat deskriptif serta cenderung memakai analisis. Ciri penelitian kualitatif ialah melaksanakan penelitian dalam keadaan yang langsung ke sumber data, peneliti jadi instrumen kunci, menyajikan data- data dalam wujud perkata ataupun foto serta tidak menekankan angka- angka, melaksanakan analisis informasi.

Metode penelitian kualitatif ini tidak dimanipulasi oleh peneliti, analisis informasi bersumber pada fakta- fakta yang ditemui di lapangan.

\section{PEMBAHASAN}

\section{Definisi Perangkat Lunak}

Perangkat lunak( software) ialah program komputer yang berhubungan dengan dokumen perangkat lunak, seperti dokumen persyaratan, dokumen model desain, dan metode penggunaan dokumen( panduan pengguna). Perangkat lunak pula biasa diucap sebagai sistem perangkat lunak. Sistem berarti sekumpulan komponen yang saling berhubungan serta mempunyai tujuan yang sama. Pengertian media pembelajaran Dalam kegiatan pendidikan, terkadang guru kesulitan buat membawakan suatu permasalahan maupun contoh, sehingga membolehkan siswa buat memahami dan menguasai isi yang di informasikan oleh guru sebagai objek dalam proses pembelajaran. Karena permasalahan tersebut, guru harus memiliki strategi, prosedur maupun metode untuk menyelesaikannya. Salah satunya 
ialah media pembelajaran." Media

yaitu bentuk jamak dari istilah media, yang dapat diartikan sebagai perantara maupun pengantar komunikasi dari pengirim kepada penerima"( Heinich et angkatan laut(AL)., 2002: Ibrahim, 1997: Ibrahim et angkatan laut(AL)., 2001). Daryanto ( 2015) melaporkan jika“ bersumber pada hal tersebut, hingga media pembelajaran yakni sarana perantara dalam proses pendidikan." Media pendidikan spesialnya yang berbasis multimedia dikala ini jadi sesuatu perlengkapan bantu yang ampuh untuk guru dalam membawakan materi dari masingmasing pendidikan. Media pembelajaran merupakan secara umum ialah alat bantu proses belajar mengajar. Segala sesuatu yang dapat dipergunakan buat memicu pikiran, perasaan, atensi dan kemampuan maupun ketrampilan pembelajar sehingga dapat mendorong terjadinya proses belajar.

Perangkat Media Pembelajaran Dalam membuat suatu media pembelajaran agar dapat mewakili dan sesuai dengan materi ajar, sampai harus dipersiapkan berbagai perangkat dalam membuatnya.
Adapun bagi Daryanto( 2015) perangkat yang digunakan dalam membuat media pendidikan ialah:

a. Bahan (Media Material) adalah sesuatu yang dapat digunakan untuk menempatkan informasi yang ingin disampaikan kepada khalayak dengan menggunakan perangkat tertentu atau bentuk dari objek itu sendiri, seperti transparansi, slide, foto, grafik, dan bahan cetak.

b. Perlengkapan (equipment) adalah sesuatu yang digunakan untuk memindahkan atau menyampaikan sesuatu yang ditempatkan oleh bahan kepada penonton, seperti proyektor slide, perekam video, papan lem, papan, dan kain flanel.

c. Perangkat keras dan perangkat lunak (hardware dan software). Perangkat keras adalah perangkat yang digunakan untuk mengirimkan informasi. Informasi ini telah dituangkan ke dalam materi untuk dikirim ke audiens. Sebaliknya, perangkat lunak adalah konten informasi yang disimpan dalam materi. 
1. Electronic learning( E- Learning)

Penafsiran electronic learning( elearning tercantum distance learning, dalam artian yang lumayan luas elearning proses pendidikan yang bisa dilaksanakan dalam ruang serta waktu yang tanpa batas. Kedatangan e- learning membagikan sebagian keuntungan semacam proses pendidikan tidak lagi dipadati oleh pengajar, tingkatan efektifitas proses belajar mengajar yang lebih besar.

E- learning pula sannggup untuk wajib mengalami sebagian hambatan semacam Menimpa adannya ketergantugan hendak tersedianya jaringan internet. Berikutnya mengerjakan latihan soal ataupun pelaksanaan yang lain di kelas. Hingga dari itu proses belajar mandiri bisa terlaksana dengan baik mengenakan portal e- learning, serta sehabis itu proses belajar mengajar dilanjutkan di kelas secara tatap muka. Pada flipped classroom, media yang dijadikan perlengkapan buat menarik atensi siswa dalam belajar yakni video.

2. Video Pembelajaran

Bermacam tipe media pendidikan, media universal mempunyai kapasitas yang lebih disukai daripada media pendidikan yang lain, perihal ini dengan alibi kalau video bisa mencampurkan sebagian media. Media video pendidikan tidak cuma dimanfaatkan oleh pengajar dalam siklus pendidikan, namun pula bisa digunakan buat mengulang kembali pelajaran yang sudah diberikan. Bukan cuma itu, hadirnya media pendidikan selaku rekaman bisa diputar kembali kapanpun serta dimanapun, mengingat terdapatnya media yang menunjang penayangan video tersebut. Serta bukan cuma itu pula, luasnya kebermanfaatan pula ialah salah satu keunggulan media video dalam interaksi pendidikan sepanjang substansi media video tersebut masih bisa diterapkan pada modul dikala ini. Buat mengantarkan video instruktif yang layak, interaksi penciptaan wajib lewat sebagian fase, tercantum aksi suasana, pengambilan foto, pengubahan serta pengujian oleh spesialis di bidang media serta konten. Terdapat pula hambatan lain yang kerap dialami, spesialnya membuat akun supaya tidak terkesan kaku, berulang- ulang supaya dapat dikemas dalam penyampaian materi yang menarik( 
Revelationni, Nur; Sulistiyo, 2017).

Selama waktu yang digunakan untuk membuat rekaman pembelajaran ini, Anda dapat memanfaatkan bantuan 2 bit pemrograman, khususnya pemrograman iMovie 9 dan Adobe Premier Elements 4. yang selama ini digunakan untuk membuat video pembelajaran ini sangatbergunapada pemrograman. Tidak cuma itu media audio visual tersebut pula dapat ditampilkan dengan dorongan aplikasi yang lain semacam sparkol video scribe. Aplikasi ini dapat digunakan untuk membuat berbagai desain animasi, dan juga bisa digunakan secara offline.

\section{Electronic books (E-Books)}

Hadirnya inovasi buku elektronik (E-book) ialah gabungan antara media novel cetak tradisional dengan inovasi berbasis Komputer yang dimanfaatkan dalam latihan- latihan pendidikan. Sama pula semacam dengan novel, tipe media lain ialah modul yang betul- betul berganti jadi maju, yang hendak diketahui dengan modul elektronik ataupun dapat diucap denganmateri maya. Rencana novel serta bahan ajar elektronik selaku media pendidikan ialah tipe bahan ajar serta bahan ajar mandiri yang bisa dipahami sehingga cocok dengan kebutuhan partisipan didik. Diperkenalkan dalam konfigurasi elektronik dilengkapi dengan fitur pendukung yang lain semacam panduan suara, kegiatan, serta pemanfaatan supaya novel serta bahan ajar jadi lebih pintar (Munawarah\&amp; Asto B, 2015). Berikut merupakan sebagian hasil dari rencana media pendidikan selaku novel digital (modul):

1. Learning Content Development System (LCDS).

LCDS merupakan aplikasi buat membuat materi pintar yang berisi bacaan, rekaman, kegiatan, foto, serta persoalan intuitif. Dengan menggunakan LCDS, hendak lebih gampang buat mengantarkan substansi informasi pendidikan.

\section{Kvisoft Flipbook Marker}

Adalah semacam program yang digunakan untuk mengubah keberadaan buku dan materi pertunjukan lainnya menjadi buku digital canggih melalui flipping book. Gadget dapat diunduh secara gratis melalui web. Pemrograman 
ulang, banyak penjual produk telah membuat aplikasi berbeda yang terkait dengan materi dan materi pembelajaran. Untuk situasi ini, jelas sederhana dalam siklus instruksi. Pembatasan perangkat keras asli sering menjadi penghalang dalam beberapa disiplin ilmu, terutama di bidang kekuasaan sejauh mencapai hasil belajar. Meskipun demikian, aplikasi sistem pengujian yang ada dapat membantu siswa dalam memahami pelajaran yang diajarkan.

Manfaat lainnya adalah untuk membatasi kesalahan dalam aplikasi yang akan dicoba. Seperti diketahui, bahan-bahan tertentu dalam medan listrik mungkin saja berisiko. Terdapat pula sebagian rujukan aplikasi yang kerap digunakan dalam pembuatan ulang modul:

Tabel 1. Beberapa Perangkat Lunak

\begin{tabular}{|l|l|}
\hline No. & $\begin{array}{l}\text { Perangkat Lunak Yang } \\
\text { Digunakan }\end{array}$ \\
\hline 1. & Festo fluidsim \\
\hline 2. & Electronics workbench \\
\hline 3. & Adobe flash \\
\hline 4. & Proteus 7.0 \\
\hline
\end{tabular}

Programer wajib mempunyai kompetensi ( ilmu pengetahuan serta keahlian atau pun kemampuan) serta cocok dengan jenjangnya mengenai sistem informasi, mempunyai pendidikan minimal D3 Ilmu Komputer serta data, ataupun berpengalaman di bidang komputer. Brainware dikelompokkan sebagai berikut:

a. Analisis Sistem,

b. Ahli Komunikasi,

c. Administrator database,

d. Programer,

e. Operator, dan

f. Pustakawan.

Pembelajaran yang mempunyai mutu yang baik, hendak menciptakan hasil belajar yang baik pula.

1. Memilih Metode Pembelajaran yang Tepat

Guru sangat diharapkan untuk bisa memilih metode belajar yang pas buat mengajar.

Apabila guru bisa memilih metode pendidikan yang pas,sehingga tujuan pembelajaran hendak tercapai dengan lebih mudah. Pemilihan metode belajar yang pas pula hendak tingkatkan motivasi belajar siswa serta atensi belajar siswa sehingga akan terbentuk suasana belajar yang mengasyikkan. 
2.Mengoptimalkan

SaranaPembelajaran

Dalam siklus belajar, pemanfaatan ruang belajar yang baik juga menjamin inspirasi belajar dalam ukuran pembelajaran internet. Pembelajaran berbasis web membutuhkan kantor yang membantu pengajaran seperti web, PC atau gadget. Pemanfaatan kantor yang baik akan meningkatkan materi yang akan diteruskan dengan meningkatkan pemanfaatan kantor yang mudah diakses.

Sekolah diandalkan untuk menawarkan bantuan paling ekstrem untuk membantu pelatihan online yang diselesaikan oleh pendidik mereka. seperti perolehan aset pembelajaran, PC yang terkait dengan web, dan instrumen yang membantu latihan pembelajaran bagi pendidik.

3. Memanfaatkan Penggunaan Media

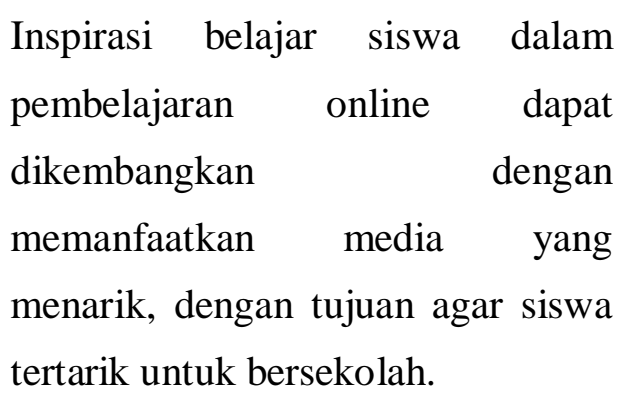

Untuk situasi ini, pendidik dapat membuat atau memanfaatkan media yang dimeriahkan untuk membantu pelatihan online. Misalnya, pendidik dapat membuat atau menggunakan media yang dimeriahkan untuk membantu interaksi instruktif, khususnya selama waktu yang dihabiskan untuk menyampaikan topik teoritis, sehingga cenderung lebih efektif dipahami dan sangat menarik. Media kegiatan yang digunakan dapat memanfaatkan powerpoint yang memikat, membuat outline yang menarik, membuat banner, atau membuat video liveness.

4. Menyelesaikan

Evaluasi Pembelajaran

Penilaian pada pembelajaran internet sangat berharga untuk dilakukan. Hal ini diharapkan dapat dilakukan penilaian pada realisasi internet dengan tujuan agar dapat terwujud dengan baik jika pembelajaran dapat berjalan dengan efektif.Jika dirasa tidak efisien hingga bisa melaksanakan modifikasi pada system pendidikan yang cocok dengan siswa. 


\section{KESIMPULAN}

Beberapa dorongan fasilitas perangkat komputer baik dari pemerintah ataupun antar sekolah, dan padahp sendiri hampir semua peserta didik menjadikan motivasi terbanyak buat memaksimalkan komputer serta hp yang terdapat dengan dorongan perangkat lunak( aplikasi) jadi media pendidikan yang efisien, kreatif serta berinovasi yang bisa tingkatkan atensi serta pencapaian belajar peserta didik demi terwujudnya kenaikan mutu kualitas Pembelajaran secara keseluruhan

Thitiporn ( 2015)
melaporkan kalau pelaksanaan
perlengkapan pendidikan membuat
siswa menguasai materi dalam
waktu yang lebih pendek.

Perangkat Media Pembelajaran Dalam membuat suatu media pembelajaran agar dapat mewakili dan sesuai dengan materi ajar, sampai harus dipersiapkan berbagai perangkat dalam membuatnya. Adapun bagi Daryanto( 2015) perangkat yang digunakan dalam membuat media pendidikan ialah:

\begin{tabular}{llr} 
a.Bahan & Media & \multicolumn{2}{c}{ Material) } \\
merupakan suatu yang bisa \\
digunakan buat menempatkan data
\end{tabular}

yang mau di informasikan kepada khalayak dengan memakai fitur tertentu ataupun wujud dari objek itu sendiri, semacam transparansi, slide, gambar, grafik, serta bahan cetak.

b. Peralatan( equipment)

suatu yang digunakan buat memindahkan ataupun mengantarkan suatu yang ditempatkan oleh bahan kepada pemirsa, semacam proyektor slide, perekam video, papan lem, papan, serta kain flanel.

c. Perangkat keras dan perangkat lunak ( hardware dan software). Perangkat keras adalah perangkat yang digunakan untuk mengirimkan informasi. Informasi ini telah dituangkan ke dalam materi untuk dikirim ke audiens. Sebaliknya, perangkat lunak adalah konten informasi yang disimpan dalam materi.

Dengan tersedianya perangkat komputer dari tiap - tiap pihak, pengajar dan peserta didik dapat memberikan kesempatan untuk melaksanakan optimalisasi lewat media pembelajaran berbasis software ( perangkat lunak). Ada 4 bentuk media pembelajaran berbasis perangkat lunak yang sangat populer ialah, e- learning, e- book, video pembelajaran serta software simulasi. 
a.Electronic learning (E- Learning)

Penafsiran electronic learning( elearning tercantum distance learning, dalam artian yang lumayan luas elearning proses pendidikan yang bisa dilaksanakan dalam ruang serta waktu yang tanpa batas. Kedatangan e- learning membagikan sebagian keuntungan semacam proses pendidikan tidak lagi dipadati oleh pengajar, tingkatan efektifitas proses belajar mengajar yang lebih besar.

E- learning pula sannggup untuk wajib mengalami sebagian hambatan semacam Menimpa adannya ketergantugan hendak tersedianya jaringan internet. Berikutnya mengerjakan latihan soal ataupun pelaksanaan yang lain di kelas.

\section{b.Video Pembelajaran}

Berbagai jenis media pembelajaran, media umum memiliki kapasitas yang lebih disukai daripada media pembelajaran lainnya, hal ini dengan alasan bahwa video dapat menggabungkan media auditif dan visual.

c. Electronic books (E-Books)

Hadirnya inovasi elektronik (E-book) ialah gabungan antara media buku cetak tradisional dengan inovasi berbasis PC yang dimanfaatkan dalam latihan-latihan pembelajaran. Sama juga seperti dengan buku, jenis media lain merupakan materi yang benar-benar berubah menjadi maju, yang akan dikenal dengan materi elektronik atau materi maya. Brainware dikelompokkan sebagai berikut:
a. Analisis Sistem,
b. Ahli Komunikasi,
c. Administrator database,
d. Programer,
e. Operator, dan
f. Pustakawan.

Ada pula pemilihan media pendidikan yang hendak diterapkan harus disesuaikan dengan kebutuhan dan kondisi partisipan didik. Pemilihan pendekatan dan model pendekatan yang cocok, serta sokongan bermacam pihak memastikan keberhasilan pembelajaran online. Evaluasi pada pendidikan online berarti buat dicoba. Mengenai ini diakibatkan dengan melakukan evaluasi pada pendidikan online sampai bisa dikenal apakah pendidikan dapat berjalan dengan efektif maupun tidak. Bila dirasa tidak efektif sampai dapat melakukan modifikasi pada system pembelajaran yang sesuai dengan kebutuhan siswa. 


\section{DAFTAR PUSTAKA}

Andriani,R.,\&Rasto,R.(2019).Motivasi belajarsebagaideterminanhasilbelajarsi swa.JurnalPendidikanManajemenPerk antoran,4(1),

Meidawati, dan S., \& Veteran BangunNusantaraSukoharjo,U.(2019). Pengaruh Daring Learning terhadapHasilBelajarIPASiswaSekolah DasarAbstrak.SeminarNasionalSains\& Entrepreneurship.

Ruri Ashari Dalimunthe, Riki Andri Yusda, William

Ramdhan.(2020).Instalasi Sistem

Operasi Berbasis Windows 10 Pada Sekolah MAN Kisaran.Jurdimas (Jurnal Pengabdian Kepada Masyarakat) Royal Vol. 3. ISSN 26223813.

Ridho Dedy Arief Budiman, Nurbani(2019). Pengembangan Media Pembelajaran Pengenalan Sistem Operasi Berbasis Android.Jurnal Pendidikan, Vol. 17. ISSN 2407-1803.

Meilani Safitri, Tria Gustiningsi , Lis Amalia. Media Pembelajaran Berbantuan Komputer: Penggunaan dan Pengaruhnya Terhadap Pemahaman Konsep Matematis Siswa SMP.Jurnal Penelitian Teknologi Pendidikan. Hanhan Hanafiah Solihin.Perancangan
Perangkat Lunak Sistem Informasi Pada Lembaga Kursus Komputer.

Muhammad Khalid Hakky , Rasyid Hardi Wirasasmita , Muhammad Zamroni Uska.(2018). Pengembangan Media Pembelajaran Berbasis Android Untuk Siswa Kelas X Pada Mata Pelajaran Sistem Operasi.Volume 2.ISSN 2549-7472.

Juna Eska ,Afrisawati, M.Ihsan ,M.Pd.(2018).Pelatihan Instalasi Sistem Operasi Windows Pada Personal Computer.Jurdimas (Jurnal Pengabdian Kepada Masyarakat) Royal Vol. 1, No. 2. ISSN 2622-381.

Suheriyanto, Ismet Basuki, Soenarjo. Pengembangan Perangkat Pembelajaran Berbasis Media Komputer Virtual dan Video dalam Model Pembelajaran Langsung.Jurnal Pendidikan Vokasi: Teori dan Praktek.Vol.2 No.1. ISSN : 2302-285X.

Sri Wahyuni.(2020). Alternatif Media Pembelajaran Berbasis Perangkat Lunak Pada Bidang Elektro.Jurnal Ilmiah Pendidikan Teknik Elektro, Vol.4. ISSN2549-3701.

Rahmawati Sidh.(2013).Peranan

Brainware Dalam Sistem Informasi Manajemen. Jurnal Computech \& Bisnis,vol 7. ISSN 2442-4943. 